\title{
Effect of Processing on the Characteristics Changes in Barnyard and Foxtail Millet
}

Nazni P* and Shobana Devi R

Department of Food Science and Nutrition, Periyar University, Salem, India

\begin{abstract}
Introduction: Millet grains, before consumption and for preparing food, are usually processed by commonly used traditional processing techniques to improve their edible, nutritional and sensory properties.

Background: The processing techniques aim to increase the physicochemical accessibility of micronutrients decrease the content of anti-nutrients or increase the content of compounds that improve bioavailability.

Objectives: Thus, an attempt was made in the present study with the objectives to study the effects of boiling, pressure cooking, roasting and germination on functional, nutritional, anti-nutritional and pasting properties of barnyard millet and foxtail millet.

Materials and Methods: Physical properties of unprocessed millets, chemical, functional, anti-nutritional and pasting properties of both unprocessed and processed millets were analysed using standard techniques.

Results and Conclusion: Physical characteristics such as thousand grain weight, thousand grain volumes, hydration capacity and index, swelling capacity and index and cooking quality of the selected two unprocessed millets were considerably differed from each other. There was a significant variation with respect to functional, nutritional, anti-nutritional and pasting properties of selected two millets in response to different processing methods. Among them, germination reduces the anti-nutritional factors while roasting significantly increases the nutritional compounds. The improved functional and pasting properties of the selected two millets were observed in the germinated and roasted millet flours.
\end{abstract}

Keywords: Barnyard millet; Foxtail millet; Functional properties; Nutritional properties; Anti nutritional parameters and pasting properties

\section{Introduction}

Millet is a collective term referring to a number of small-seeded annual grasses that are cultivated as grain crops, primarily on marginal lands in dry areas in temperate, subtropical and tropical regions. The most important species are barnyard millet and foxtail millet. Foxtail millet is important in parts of Asia (mainly China) and Europe. The other species barnyard millet is locally important food grains restricted to smaller regions or individual countries. The various species differ in their physical characteristics, quality attributes, soil and climatic requirements and growth duration [1].

Cereal grains are the most important source of the world's food and have a significant role in the human diet throughout the world. Millets are also rich sources of phytochemicals and micronutrients [2]. As a food source it is non-glutinous and non- acid forming, so is soothing and easy to digest. It is considered to be one of the least allergenic grains. It is high in quality protein, contains high fibre, B-complex vitamins and also the vitamins A and E [3]. Millets may serve as a natural source of antioxidants in food applicants and as a nutraceutical and functional food ingredient in health promotion and disease risk reduction. Millets are also rich sources of non-nutritional components like phenols, tannins, phytate and flavonoids. These compounds serves as an antioxidant and millets could also be used as source of extremely beneficial phytochemicals in the pharmaceutical and food industry [4]. Therefore, millet grains are now receiving specific attention from the developing countries in terms of utilization as food as well as from some developed countries in terms of its good potential in the manufacturing of bioethanol and biofilms [5].

Millet grains, before consumption and for preparing food, are usually processed by commonly used traditional processing techniques to improve their edible, nutritional and sensory properties [6]. The processing techniques aim to increase the physicochemical accessibility of micronutrients, decrease the content of antinutrients or increase the content of compounds that improve bioavailability [7]. Thus, an attempt was made in the present study with the objectives to study the effects of wet heat treatment (boiling and pressure cooking), dry heat treatment (roasting) and germination on physicochemical, functional, anti-nutritional and pasting properties of barnyard millet, and foxtail millet.

\section{Materials and Methods}

The selected two millets namely barnyard millet and foxtail millet were procured from local market of Vellore district, Tamil Nadu, India. The millets were cleaned properly and stored in sealed containers.

*Corresponding author: Nazni $\mathrm{P}$, Department of Food Science and Nutrition Periyar University, Salem, India, Tel: +919884817954; E-mail: naznip@gmail.com

Received January 11, 2016; Accepted February 02, 2016; Published February 09,2016

Citation: Nazni P, Devi SR (2016) Effect of Processing on the Characteristics Changes in Barnyard and Foxtail Millet. J Food Process Technol 7: 566. doi:10.4172/2157-7110.1000566

Copyright: $\odot 2016$ Nazni $P$, et al. This is an open-access article distributed unde the terms of the Creative Commons Attribution License, which permits unrestricted use, distribution, and reproduction in any medium, provided the original author and source are credited. 


\section{Physical characterization of selected two unprocessed millet grains}

Physical characteristics such as thousand grain weights, thousand grain volumes, hydration capacity and index, swelling capacity and index, cooking quantity/characteristics were analyzed for the selected two unprocessed millet grains using standard procedures in triplicates.

\section{Processing of selected two millet grains in to flours}

Food processing is the transformation of raw ingredients, by physical or chemical means into food, or of food into other forms. It is widely accepted that simple and inexpensive traditional processing techniques are effective methods of achieving desirable changes in the composition of grains. The processing methods such as boiling, germination, pressure cooking and roasting were implemented with raw sample to test the effect of processing on functional, chemical, anti-nutritional and pasting characteristics of millet grains.

\section{Functional properties of raw and processed millet flours}

The functional properties such as bulk density, swelling power, solubility, solid loss, water absorption capacity and oil absorption capacity were analyzed using standard procedure in triplicates. Bulk density of each sample was determined by the method described by Ige et al. [8]. Swelling power, solubility and solid loss of the raw and processed millet flours was determined using the modified method of Shin et al. [9]. The water and oil absorption capacity were determined using the method described by Lin et al. [10].

\section{Nutrient analysis of raw and processed millet flours}

Proximate composition such as $\mathrm{pH}$, moisture, ash, total titrable acidity, crude protein, crude fibre, carbohydrate, fat, energy, amylose content, total starch and mineral composition like sodium, potassium, calcium, iron and phosphorus were determined for the selected two raw and processed millet flours using standard procedures.

\section{Anti nutritional parameters of raw and processed millet flours}

Anti-nutrients are natural or synthetic compounds that when present in foods reduce the availability of the nutrients. The antinutritional parameters such as tannin, total phenolics and trypsin inhibitor were determined using standard procedures as described by Sadasivam and Manickam [11].

\section{Pasting properties of raw and processed millet flours}

Pasting properties of the selected two raw and processed millet flours were analyzed using Rapid Visco Analyzer (RVA) as described by Tester and Morrison [12]. Parameters recorded were pasting temperature, peak viscosity, trough viscosity (minimum viscosity at $95^{\circ} \mathrm{C}$ ), final viscosity (viscosity at $50^{\circ} \mathrm{C}$ ), breakdown viscosity (peaktrough viscosity), and setback viscosity (final-trough viscosity). The pasting properties of each sample were determined from $3 \mathrm{~g}$ of flour (dry basis) in $25 \mathrm{ml}$ of distilled water by using a Rapid Visco Analyzer (RVA) model 3D (Newport Scientific Pty. Ltd., Australia). The sample was heated from 50 to $95^{\circ} \mathrm{C}$ at the rate of $12^{\circ} \mathrm{C} / \mathrm{min}$ with constant stirring at $160 \mathrm{rpm}$ and held at $95^{\circ} \mathrm{C}$ for 2.5 minutes (break down), then cooled at $50^{\circ} \mathrm{C}$ at the rate of $13^{\circ} \mathrm{C} / \mathrm{min}$ (set back) and held for 2 minutes. The total cycle was 12.5 minutes. Pasting temperature was recorded as the temperature at which an increase in viscosity was first observed. The values reported included pasting temperature $\left({ }^{\circ} \mathrm{C}\right)$, Peak viscosity $(\mathrm{cP})$, final viscosity $(\mathrm{cP})$, trough (lowest viscosity, $\mathrm{cP})$, break down (difference between peak viscosity and trough, $\mathrm{cP}$ ), set back from peak (the difference between final viscosity and peak viscosity, $\mathrm{cP}$ ) and set back from trough (the difference between final viscosity and trough, $\mathrm{cP}$ ).

\section{Statistical analysis}

The final data was compiled and analyzed using suitable statistical methods. The results were represented as descriptive statistics such as mean, standard deviation and one way ANOVA. pvalues $<0.05$ were considered significant. Analysis of variance (ANOVA) was used to test the differences among different processed millet flours. The data reported in tables are an average of triplicate observations subjected to one-way analysis of variance (ANOVA).

\section{Results and Discussion}

\section{Physical characteristics of selected two unprocessed millet grains}

The physical characteristics such as thousand grain weight, thousand grain volume, hydration capacity and index, swelling capacity and index and cooking quantity/characteristics of selected two unprocessed millets grains were presented in Table 1 . The thousand grain weight of barnyard millet and foxtail millet were $3.69 \mathrm{~g}$ and $2.64 \mathrm{~g}$ respectively. The thousand grain volume of barnyard millet was $4.01 \mathrm{ml}$ and $2.96 \mathrm{ml}$ for foxtail millet. Grain volumes change significantly and most often, regularly at varying moisture contents.

The hydration capacity of the barnyard millet and foxtail millet were $2.93 \mathrm{~g} / 1000$ seeds and $2.01 \mathrm{~g} / 1000$ seeds with the hydration index of $78.39 \%$ and $76.9 \%$ respectively. The barnyard millet grain was found to have swelling capacity of $0.23 \mathrm{ml} / 1000$ seeds with an index of $5.83 \%$ and foxtail millet grain was observed to have swelling capacity of 0.21 $\mathrm{ml} / 1000$ seeds with an index of $6.72 \%$. The presence of high protein, lipid, fiber and larger amount of amylose-lipid complex in flour could inhibit the swelling of starch granules [13].

Cooking quality of the grain is an important criterion to assess the consumer acceptability [14]. The barnyard millet and foxtail millet grains required 12 minutes to get cooked. The increase in the weight of barnyard millet and foxtail millet grains after cooking were $175.6 \%$ and $197.6 \%$ respectively. The increase in the volume of barnyard millet and foxtail millet grains after cooking were $41.2 \%$ and $75.5 \%$ respectively.

\section{Functional properties of selected two raw and processed millet flours}

The functional properties such as bulk density, swelling power, solubility, solid loss, water absorption capacity and oil absorption capacity of the selected two raw and processed millet flours were discussed below.

\begin{tabular}{|c|c|c|c|}
\hline S.no & Parameters & Barnyard millet & Foxtail millet \\
\hline 1. & Thousand grain weight $(\mathrm{g})$ & $3.69 \pm 0.01$ & $2.64 \pm 0.005$ \\
\hline 2. & Thousand grain Volume $(\mathrm{ml})$ & $4.01 \pm 0.01$ & $2.96 \pm 0.05$ \\
\hline 3. & Hydration Capacity (g/1000 seeds) & $2.93 \pm 0.05$ & $2.01 \pm 0.02$ \\
\hline 4. & Hydration Index (\%) & $78.39 \pm 0.1$ & $76.9 \pm 0.05$ \\
\hline 5. & Swelling Capacity (ml/1000 seeds) & $0.23 \pm 0.05$ & $0.21 \pm 0.02$ \\
\hline 6. & Swelling Index (\%) & $5.83 \pm 1.44$ & $6.72 \pm 0.02$ \\
\hline 7. & Gain in weight after cooking (\%) & $175.6 \pm 10.6$ & $197.6 \pm 14.0$ \\
\hline 8. & Gain in volume after cooking (\%) & $41.2 \pm 3.76$ & $75.5 \pm 2.07$ \\
\hline 9. & Cooking time (minutes) & 12 minutes & 12 minutes \\
\hline
\end{tabular}

Table 1: Physical characteristics of selected two unprocessed millet grains. 


\section{Bulk Density of the raw and processed millet flours}

The bulk density of the selected two raw and processed millet flours was presented in Table 2. Bulk density is an important parameter that determines the packaging requirement of a product [15]. In comparison with raw millet flours, the bulk density of the boiled, pressure cooked and roasted samples were significantly increased $(\mathrm{p}<0.05)$ whereas the bulk density of the germinated millet flours of selected two millets was decreased. The decreased bulk density of the germinated millet flour indicates low porosity or air spacing in the flour, therefore less autooxidation. This is an advantage in respect to spoilage, packing and transportation as goods in relation to weight [16].

\section{Swelling power of the raw and processed millet flours}

Swelling and water absorption capacities are important parameters in determining the sample consistency (solid, semi-solid and liquid) and are dependent on the compositional structure of the sample [17]. The swelling power of the selected two raw and processed millet flours was given in Table 3. The swelling power of the selected two processed millet flours at $90^{\circ} \mathrm{C}$ were consistently reduced when compared with raw samples and does not varied significantly with each other $(p>0.05)$. The swelling behaviour below $16 \mathrm{~g} / \mathrm{g}$ is considered as highly restricted. This restricted swelling behaviour of the flour samples indicates its stability against shearing action when subjected to heat [18]. Therefore, in the present study, the selected two raw and processed millet flours showed restricted swelling behaviour indicate its resistant power towards heating.

\section{Solubility behaviour of the raw and processed millet flours}

Solubility is an indicator of the degree of starch granules dispersion after cooking [19]. Solubility behaviour of the selected two raw and processed millet flours at $90^{\circ} \mathrm{C}$ was presented in Table 4. Among all the processing techniques of selected two millets, germinated millet flour contained highest solubility behaviour. The solubility could imply to the amount of amylose leaching out from starch granule when swelling, therefore the higher the solubility the higher will be the amylose leaching [20]. Difference in solubility could also be attributed to different chain length distribution in the starch [21].

\section{Solid loss of the raw and processed millet flours}

Solid loss of the selected two raw and processed millet flours was shown in the Table 5. The processed barnyard millet flour exhibited loss of solids to an extent of $27.9 \%$ in boiled, $26.5 \%$ in germinated, $29.1 \%$ in pressure cooked, $30.1 \%$ in roasted and $30.7 \%$ in raw samples. The cooking of processed foxtail millet flour resulted in $27.5 \%$ of solid loss in boiled, $27 \%$ in germinated, $30.5 \%$ in pressure cooked, $28.4 \%$ in roasted and $29.3 \%$ in raw samples. A significant difference in solid loss was observed between different processed barnyard and foxtail millet flours $(\mathrm{p}<0.05)$.

\begin{tabular}{|c|c|c|c|}
\hline S.no & Processing techniques & Barnyard millet (g/ml) & Foxtail millet (g/ml) \\
\hline 1. & Boiling & $0.62 \pm 0.005^{\mathrm{a}}$ & $0.70 \pm 0.005^{\mathrm{a}}$ \\
\hline 2. & Germination & $0.44 \pm 0.005^{\mathrm{b}}$ & $0.43 \pm 0.005^{\mathrm{b}}$ \\
\hline 3. & Pressure cooking & $0.52 \pm 0.03^{\mathrm{c}}$ & $0.53 \pm 0.01^{\mathrm{c}}$ \\
\hline 4. & Roasting & $0.55 \pm 0.005^{\mathrm{c}}$ & $0.53 \pm 0.01^{\mathrm{c}}$ \\
\hline 5. & Raw & $0.50 \pm 0.005^{\mathrm{c}}$ & $0.52 \pm 0.005^{\mathrm{c}}$ \\
\hline
\end{tabular}

The values are expressed as the mean of three replicate samples $\pm S D$. Values in a column with different superscripts differ significantly $(p<0.05)$.

Table 2: Bulk Density of the raw and processed millet flours.

\begin{tabular}{|c|c|c|c|}
\hline S.no & Processing techniques & Barnyard millet $\mathbf{( g / g )}$ & Foxtail millet $\mathbf{( g / g})$ \\
\hline 1. & Boiling & $4.73 \pm 0.3$ & $4.83 \pm 0.45$ \\
\hline 2. & Germination & $4.53 \pm 0.35$ & $4.63 \pm 0.4$ \\
\hline 3. & Pressure cooking & $4.7 \pm 0.17$ & $5.16 \pm 0.4$ \\
\hline 4. & Roasting & $4.96 \pm 0.15$ & $4.9 \pm 0.3$ \\
\hline 5. & Raw & $5.2 \pm 0.2$ & $5.23 \pm 0.4$ \\
\hline
\end{tabular}

The values are expressed as the mean of three replicate samples \pm SD. Values in a column do not differ significantly $(p>0.05)$.

Table 3: Swelling power of the raw and processed millet flours.

\begin{tabular}{|c|c|c|c|}
\hline S.no & Processing techniques & Barnyard millet (\%) & Foxtail millet (\%) \\
\hline 1. & Boiling & $6.3 \pm 0.41^{\mathrm{a}}$ & $6.3 \pm 0.55^{\mathrm{a}}$ \\
\hline 2. & Germination & $6.8 \pm 0.41^{\mathrm{a}}$ & $7.1 \pm 0.55^{\mathrm{b}}$ \\
\hline 3. & Pressure cooking & $6.7 \pm 0.60^{\mathrm{a}}$ & $5.8 \pm 0.60^{\mathrm{c}}$ \\
\hline 4. & Roasting & $6.3 \pm 0.55^{\mathrm{a}}$ & $5.4 \pm 0.45^{\mathrm{d}}$ \\
\hline 5. & Raw & $6.2 \pm 0.26^{\mathrm{a}}$ & $6.2 \pm 0.55^{\mathrm{a}}$ \\
\hline
\end{tabular}

The values are expressed as the mean of three replicate samples \pm SD. Values with similar superscripts in a column do not differ significantly. Values with different superscripts in a column differ significantly.

Table 4: Solubility behaviour of the raw and processed millet flours.

\begin{tabular}{|c|c|c|c|}
\hline S.no & Processing techniques & Barnyard millet (\%) & Foxtail millet (\%) \\
\hline 1. & Boiling & $27.9 \pm 1.45^{\mathrm{a}}$ & $27.5 \pm 0.87^{\mathrm{a}}$ \\
\hline 2. & Germination & $26.5 \pm 1.30^{\mathrm{b}}$ & $27 \pm 1.76^{\mathrm{b}}$ \\
\hline 3. & Pressure cooking & $29.1 \pm 1.55^{\mathrm{c}}$ & $30.5 \pm 1.21^{\mathrm{c}}$ \\
\hline 4. & Roasting & $30.1 \pm 1.34^{\mathrm{d}}$ & $28.4 \pm 0.96^{\mathrm{d}}$ \\
\hline 5. & Raw & $30.7 \pm 0.90^{\mathrm{e}}$ & $29.3 \pm 0.86^{\mathrm{e}}$ \\
\hline
\end{tabular}

The values are expressed as the mean of three replicate samples \pm SD. Values with different superscripts in a column differ significantly.

Table 5: Solid loss of the raw and processed millet flours.

\section{Water absorption capacity of the raw and processed millet} flours

The water absorption capacity of the selected two raw and processed millet flours was presented in the Table 6. Water absorption capacity is important in the development of ready to eat foods, and high absorption capacity may assure product cohesiveness [22]. The variations in water absorption capacity of the selected two processed millets is highly attributed by several factors such as number of hydration positions, physical environment, $\mathrm{pH}$, solvent, presence of lipids and carbohydrates [23]. In the present study, water absorption capacity was significantly increased $(\mathrm{p}<0.05)$ in boiled, pressure cooked and roasted samples compared to raw samples, but germinated millet flours of selected two millets have least water absorption capacity. When the lipid content is high in the flour, the water absorption decreases because lipids block the polar sites of the proteins attenuating the absorption of water [24].

Oil absorption capacity of the raw and processed millet flours

Table 7 shows the oil absorption capacity of the selected two raw and processed millet flours. The high oil absorption capacity makes the flours suitable for facilitating enhancement in flavour and mouth feel when used in food preparations [25]. Oil absorption capacity was significantly increased $(p<0.05)$ in boiled, germinated; pressure cooked and roasted millet flours compared to raw samples. Variation in fat absorption may be due to the variation in protein concentration, degree of interaction with water and oil and conformational characteristics [26]. 


\section{Nutrient analysis of selected two raw and processed millet flours}

Proximate composition such as $\mathrm{pH}$, moisture, ash, total titrable acidity, crude protein, crude fibre, carbohydrate, fat, energy, amylose content, total starch and mineral composition like sodium, potassium, calcium, iron and phosphorus analyzed for the selected two raw and processed millet flours were discussed below.

\section{Proximate composition of selected two raw and processed millet flours}

The proximate composition of raw and processed barnyard millet flour was tabulated in Table 8. The $\mathrm{pH}$ value of the boiled, germinated, pressure cooked, roasted and raw samples were 7, 6.5, 6.8, 6.7 and 7.1 respectively. The total ash content of the raw and processed barnyard millet flour ranged from $2 \mathrm{~g}$ to $2.5 \mathrm{~g}$. The ash content of the samples is the reflection of minerals. Hence the barnyard millets are rich in minerals. The highest total titrable acidity was noticed in germinated barnyard millet flour $0.72 \mathrm{~g}$ and lowest value was seen in pressure cooked sample $0.32 \mathrm{~g}$. The higher the moisture content the lower the dry matter yield on drying [27]. The raw barnyard millet flour contained high moisture content of $10 \mathrm{~g}$, followed by germinated $9.5 \mathrm{~g}$, boiled $8 \mathrm{~g}$, pressure cooked $7.4 \mathrm{~g}$ and roasted $6.2 \mathrm{~g}$ [28-31], found that total protein

\begin{tabular}{|c|c|c|c|}
\hline S.no & Processing techniques & Barnyard millet $\mathbf{( g / g )}$ & Foxtail millet $\mathbf{( g / g})$ \\
\hline 1. & Boiling & $2.40 \pm 0.02^{\mathrm{a}}$ & $1.86 \pm 0.04^{\mathrm{a}}$ \\
\hline 2. & Germination & $1.12 \pm 0.01^{\mathrm{b}}$ & $0.95 \pm 0.02^{\mathrm{b}}$ \\
\hline 3. & Pressure cooking & $2.31 \pm 0.02^{\mathrm{c}}$ & $2.06 \pm 0.04^{\mathrm{c}}$ \\
\hline 4. & Roasting & $1.59 \pm 0.01^{\mathrm{d}}$ & $1.39 \pm 0.06^{\mathrm{d}}$ \\
\hline 5. & Raw & $1.24 \pm 0.04^{\mathrm{e}}$ & $1.18 \pm 0.05^{\mathrm{e}}$ \\
\hline
\end{tabular}

The values are expressed as the mean of three replicate samples \pm SD. Values with different superscripts in a column differ significantly.

Table 6: Water absorption capacity of the raw and processed millet flours.

\begin{tabular}{|c|c|c|c|}
\hline S.no & Processing techniques & Barnyard millet $\mathbf{( g / g )}$ & Foxtail millet $\mathbf{( g / g})$ \\
\hline 1. & Boiling & $1.14 \pm 0.03^{\mathrm{a}}$ & $1.17 \pm 0.04^{\mathrm{a}}$ \\
\hline 2. & Germination & $1.12 \pm 0.03^{\mathrm{b}}$ & $1.26 \pm 0.02^{\mathrm{b}}$ \\
\hline 3. & Pressure cooking & $1.39 \pm 0.05^{\mathrm{c}}$ & $1.15 \pm 0.03^{\mathrm{c}}$ \\
\hline 4. & Roasting & $1.16 \pm 0.05^{\mathrm{d}}$ & $1.12 \pm 0.03^{\mathrm{d}}$ \\
\hline 5. & Raw & $1.10 \pm 0.01^{\mathrm{e}}$ & $1.06 \pm 0.02^{\mathrm{e}}$ \\
\hline
\end{tabular}

The values are expressed as the mean of three replicate samples \pm SD. Values with different superscripts in a column differ significantly.

Table 7: Oil absorption capacity of the raw and processed millet flours.

\begin{tabular}{|c|c|c|c|c|c|c|}
\hline S.no & Parameters & Boiling & Germination & $\begin{array}{c}\text { Pressure } \\
\text { cooking }\end{array}$ & Roasting & Raw \\
\hline 1. & pH & 7.00 & 6.5 & 6.8 & 6.7 & 7.1 \\
\hline 2. & Ash (g) & 2.5 & 2.0 & 2.4 & 2.2 & 2.3 \\
\hline 3. & $\begin{array}{c}\text { Total titrable } \\
\text { Acidity (g) }\end{array}$ & 0.48 & 0.72 & 0.32 & 0.36 & 0.46 \\
\hline 4. & Moisture (g) & 8 & 9.5 & 7.4 & 6.2 & 10 \\
\hline 5. & Crude Protein (g) & 7.4 & 8.9 & 8.3 & 12.8 & 11.2 \\
\hline 6. & Crude Fibre (g) & 6.4 & 5.7 & 7.2 & 7.0 & 5.3 \\
\hline 7. & Carbohydrates (g) & 72 & 61 & 80 & 75 & 72 \\
\hline 8. & Fat (g) & 3.4 & 2.5 & 3.0 & 1.9 & 1.8 \\
\hline 9. & Energy (Kcals) & 348.2 & 302.1 & 380.2 & 368.3 & 349 \\
\hline 10. & Total Starch (g) & 17.2 & 7.8 & 13.59 & 10.32 & 12.6 \\
\hline 11. & $\begin{array}{c}\text { Amylose content } \\
\text { (\%) }\end{array}$ & 15.22 & 10.8 & 12 & 9.6 & 8 \\
\hline
\end{tabular}

Table 8: Proximate composition of the raw and processed barnyard millet flour (per 100 gms) increased after germination process. In this study, the results showed that roasted barnyard millet flour contained high protein content (12.8 g) when compared to other processed samples.

The fibre content of the raw and processed barnyard millet flour ranged from $5.3 \mathrm{~g}$ to $7.2 \mathrm{~g}$, being the highest for pressure cooked flour $7.2 \mathrm{~g}$ and lowest for raw flour $5.3 \mathrm{~g}$. It is generally accepted that the consumption of food naturally rich in dietary fibre is beneficial to the maintenance of health [32]. The carbohydrate content of the boiled barnyard millet flour was $72 \mathrm{~g}, 61 \mathrm{~g}$ for germinated, $80 \mathrm{~g}$ for pressure cooked, $75 \mathrm{~g}$ for roasted and $72 \mathrm{~g}$ for raw samples. The carbohydrate content of the germinated barnyard millet flour was comparatively lesser than the other processed samples. This results were in agreement with Mubarak [33], reported that germinated samples showed a significant reduction in the total carbohydrate. The decrease in the carbohydrate during the process of germination is due to the use of carbohydrate for metabolism by the sprouts [34].

Among the fat content of barnyard millet flour, the roasted and raw flour contained less fat content of $1.9 \mathrm{~g}$ and $1.8 \mathrm{~g}$ respectively. This results confirms with the report of Aremu, et al. [35] stated that kersting groundnut and cranberry bean upon roasting were found to greatly reduce crude fat content. The energy value of raw and processed flour varied from $302.1 \mathrm{kcals}$ to $380.2 \mathrm{kcals}$. The lowest energy value was observed in germinated flour (302.1 kcals) and the highest energy value was observed in pressure cooked flour $(380.2 \mathrm{kcals})$ due to its high carbohydrate and fat content. The total starch content of raw and processed barnyard millet flour ranged from $7.8 \mathrm{~g}$ to $17.2 \mathrm{~g}$, being the highest in boiled $17.2 \mathrm{~g}$ and lowest in germinated flour $7.8 \mathrm{~g}$. Germination of proso millet grains decreased the dry weight and the total starch content [36]. All the processing methods were exhibited increased amylose content of barnyard millet flour compared to raw flour. The boiled sample contained high amylose content of $15.22 \%$, followed by pressure cooked $12 \%$, germinated $10.8 \%$, roasted $9.6 \%$ and raw sample of $8 \%$.

Grains are the store houses of many chemical components including nutrients, phytochemicals, and non-nutritive plant protective functional constituents. The nutritional content of the raw and processed foxtail millet flour was tabulated in Table 9. The $\mathrm{pH}$ value of boiled, germinated, pressure cooked, roasted and raw foxtail millet flour was $6.7,7.2,6.5,6.2$ and 7.0 respectively. The ash content of the raw and processed foxtail millet flour ranged from $2.1 \mathrm{~g}$ to 4.2 g. This indicates the high mineral content of foxtail millet flour. Ash is the inorganic residue remaining after the water and organic matter have been removed by heating in the presence of oxidizing agents which provides a measure of the total amount of minerals within a food. Regarding the total titrable acidity, the highest value was found in germinated sample $(0.55 \mathrm{~g})$, followed by $0.54 \mathrm{~g}$ in raw, $0.45 \mathrm{~g}$ in roasted, $0.34 \mathrm{~g}$ in boiled and $0.32 \mathrm{~g}$ in pressure cooked samples. The moisture content of boiled ( $6.46 \mathrm{~g})$, germinated $(11.56 \mathrm{~g})$, pressure cooked ( 7.3 g) and roasted foxtail millet flour $(7.56 \mathrm{~g})$ was comparatively lesser than the raw millet flour $(15 \mathrm{~g})$. This indicates the less susceptibility to microbial infection. The high protein content was seen in germinated flour $(12.6 \mathrm{~g})$ were in agreement with the report of Srichuwong et al. [37] stated that process of germination greatly attributed protein increase to protein synthesis due to inclusion of microbial cells in to the flour.

The crude fibre content ranged from $4.9 \mathrm{~g}$ to $6.1 \mathrm{~g}$. processing of foxtail millet flour showed an increase in the fibre content compared to raw flour. Germination can increase dietary fibre content than other processing and increase mineral bioavailability $[38,39]$. The 
carbohydrate content of processed foxtail millet flour was significantly reduced when compared to raw millet flour except germinated sample which exhibits higher content of carbohydrates $(72 \mathrm{~g})$. Fat content was increased in roasted sample $(3.2 \mathrm{~g})$, followed by raw $(2.9 \mathrm{~g})$, pressure cooked (2.8 g), germinated (2.6 g) and boiled sample (1.9 g). The calorific value of foxtail millet flour exhibited $302.7 \mathrm{kcals}$ in boiled, $361.8 \mathrm{kcals}$ in germinated, $332 \mathrm{kcals}$ in pressure cooked, $294.4 \mathrm{kcals}$ in roasted and $333.3 \mathrm{kcals}$ in raw samples. The high calorific value of germinated flour was due to its high protein and high carbohydrate content. The total starch content of the processed foxtail millet flour was drastically reduced compared to raw flour. It has been observed as $13.6 \mathrm{~g}$ of starch in boiled, $11.9 \mathrm{~g}$ in germinated, $8.62 \mathrm{~g}$ in pressure cooked, $7.85 \mathrm{~g}$ in roasted and $18.5 \mathrm{~g}$ in raw kodo millet flour. The pressure cooked sample contained high level of amylose $(12.4 \%)$, followed by germinated $(10.8 \%)$, boiled $(6.8 \%)$, roasted $(4.4 \%)$ and raw flour $(4 \%)$.

\section{Mineral composition of selected two raw and processed millet flours}

The mineral composition of raw and processed barnyard millet flour were shown in the Table 10.The sodium content of the raw and processed barnyard millet flour ranged from $13 \mathrm{mg}$ to $20 \mathrm{mg}$, being the highest for pressure cooked flour $(20 \mathrm{mg})$ and lowest for boiled barnyard millet flour $(13 \mathrm{mg})$. The potassium content of processed barnyard millet flour was significantly reduced compared to raw flour. Boiled sample has $210 \mathrm{mg}$ of potassium, $215 \mathrm{mg}$ in germinated, $225 \mathrm{mg}$ in pressure cooked, $248 \mathrm{mg}$ in roasted and $298 \mathrm{mg}$ in raw samples. Iron content was decreased when grains were roasted [40]. This statement was in agreement with the current study findings revealed that roasted barnyard millet flour exhibited less iron content $(3.28 \mathrm{mg})$ than other processing techniques. The calcium and phosphorus content of the processed barnyard millet flour were decreased when compared with raw millet flour. Processing techniques were considerably affected the calcium and phosphorus content of the barnyard millet. It has been

\begin{tabular}{|c|c|c|c|c|c|c|}
\hline S.no & Parameters & Boiling & Germination & $\begin{array}{r}\text { Pressure } \\
\text { cooking }\end{array}$ & Roasting & Raw \\
\hline 1. & pH & 6.7 & 7.2 & 6.5 & 6.2 & 7.0 \\
\hline 2. & Ash (g) & 2.8 & 4.2 & 3.4 & 2.6 & 2.1 \\
\hline 3. & Total titrable Acidity & 0.34 & 0.55 & 0.32 & 0.45 & 0.54 \\
\hline (g) & Moisture (g) & 6.46 & 11.56 & 7.3 & 7.56 & 15 \\
\hline 5. & Crude Protein (g) & 8.4 & 12.6 & 7.7 & 10.4 & 6.8 \\
\hline 6. & Crude Fibre (g) & 6.1 & 5.1 & 5.9 & 5.1 & 4.9 \\
\hline 7. & Carbohydrates (g) & 63 & 72 & 69 & 56 & 70 \\
\hline 8. & Fat (g) & 1.9 & 2.6 & 2.8 & 3.2 & 2.9 \\
\hline 9. & Energy (Kcals) & 302.7 & 361.8 & 332 & 294.4 & 333.3 \\
\hline 10. & Total Starch (g) & 13.6 & 11.9 & 8.62 & 7.85 & 18.5 \\
\hline 11. & Amylose content (\%) & 6.8 & 10.8 & 12.4 & 4.4 & 4 \\
\hline
\end{tabular}

Table 9: Proximate composition of the raw and processed foxtail millet flour (per $100 \mathrm{gms})$.

\begin{tabular}{|c|c|c|c|c|c|c|}
\hline S.no & Minerals & Boiling & Germination & $\begin{array}{c}\text { Pressure } \\
\text { cooking }\end{array}$ & Roasting & Raw \\
\hline 1. & Sodium (mg) & 13 & 17 & 20 & 14 & 18 \\
\hline 2. & Potassium (mg) & 210 & 215 & 225 & 248 & 298 \\
\hline 3. & Iron (mg) & 3.3 & 7.59 & 8.9 & 3.28 & 9.0 \\
\hline 4. & Calcium (mg) & 30 & 50 & 32 & 40 & 60 \\
\hline 5. & Phosphorus (mg) & 252 & 210 & 227 & 234 & 252 \\
\hline
\end{tabular}

Table 10: Mineral composition of the raw and processed barnyard millet flour (per 100 gms). observed as $30 \mathrm{mg}$ of calcium in boiled, $50 \mathrm{mg}$ in germinated, $32 \mathrm{mg}$ in pressure cooked, $40 \mathrm{mg}$ in roasted and $60 \mathrm{mg}$ in raw millet flour. Whereas phosphorus content of boiled barnyard millet flour was 252 $\mathrm{mg}, 210 \mathrm{mg}$ in germinated, $227 \mathrm{mg}$ in pressure cooked, $234 \mathrm{mg}$ in roasted and $252 \mathrm{mg}$ in raw flour.

Table 11 showed the mineral content of the raw and processed foxtail millet flour. When compared to raw flour, the sodium and potassium content of the processed foxtail millet flour were considerably increased. The sodium and potassium content was ranged from $8 \mathrm{mg}$ to $25 \mathrm{mg}$ and $252 \mathrm{mg}$ to $356 \mathrm{mg}$ respectively. Germinated foxtail millet flour found to have high iron content $(5.8 \mathrm{mg})$ followed by pressure cooked $3.8 \mathrm{mg}$, raw $3.7 \mathrm{mg}$, boiled $2.59 \mathrm{mg}$ and roasted 2.4 mg. Germination or malting generally improves the nutrient content and digestibility of foods and it could be an appropriate food-based strategy to derive iron and other minerals maximally from food grains [41]. In this study, processing exhibited desirable changes in the calcium and phosphorus content. The calcium content of the raw and processed foxtail millet flour ranged from $31 \mathrm{mg}$ to $60 \mathrm{mg}$, whereas the phosphorus content varied from $221 \mathrm{mg}$ to $280 \mathrm{mg}$.

\section{Anti-nutritional parameters of selected two raw and processed millet flours}

The anti-nutritional parameters of the selected two raw and processed millet flours were analyzed to determine the effect of processing on anti-nutrients such as tannin, total phenolics and trypsin inhibitor.

Anti-nutritional parameters of raw and processed barnyard millet flour were shown in Figure 1. An increase in the tannin, total phenolics and trypsin inhibitor levels was noticed in processed barnyard millet flour when compared to raw flour. This was in agreement with the study conducted by Seifi et al. [42] also revealed that during processing, an increase in the content of tannin, total phenolics and trypsin inhibitor activity was noticed in little millets compared to the native millets.

The anti-nutritional parameters of raw and processed foxtail millet flour were shown in Figure 2. Among the different processing techniques, the pressure cooked foxtail millet flour showed high level of tannin content $(0.41 \mathrm{mg} / \mathrm{g})$. The total phenolics content was found to be high in roasted $(68.1 \mathrm{mg} / \mathrm{g})$ and pressure cooked $(67.2$ $\mathrm{mg} / \mathrm{g}$ ) foxtail millet flour. Longer the cooking time, the greater losses of the total phenolic compound measured. This could be due to the breakdown of phenolics or losses (leached out) during cooking as most of the bioactive compounds are relatively unstable to heat and easily solubilised. The trypsin inhibitor content of processed foxtail millet flour was considerably reduced with that of raw flour. Cooking by boiling, germinating and frying resulted in a significant reduction in the trypsin inhibitor content of tomatoes [43].

\section{Pasting properties of the selected two raw and processed millet flours}

Pasting properties are the important factors in determining the application values of flours and starches [44]. Tables 12 and 13 shows the pasting properties of the raw and processed barnyard millet flour and foxtail millet flour respectively. Pasting temperature is an indication of minimum temperature required for cooking the samples [45]. Pasting temperature of the raw and processed barnyard millet flour ranged from $48.25^{\circ} \mathrm{C}$ to $94.45^{\circ} \mathrm{C}$, being the highest for roasted sample $\left(94.45^{\circ} \mathrm{C}\right)$ and lowest for boiled sample $\left(48.25^{\circ} \mathrm{C}\right)$. Pasting temperature of the raw and processed foxtail millet flour ranged from $48.5^{\circ} \mathrm{C}$ to $89.6^{\circ} \mathrm{C}$ being the highest for raw foxtail millet flour $\left(89.6^{\circ} \mathrm{C}\right)$ 
Citation: Nazni P, Devi SR (2016) Effect of Processing on the Characteristics Changes in Barnyard and Foxtail Millet. J Food Process Technol 7: 566. doi:10.4172/2157-7110.1000566

Page 6 of 8

and lowest for both boiled and pressure cooked foxtail millet flour $\left(48.5^{\circ} \mathrm{C}\right)$.

Peak viscosities attained during the heating portion of tests indicates the water binding capacity of starch mixture. This often correlates with the final product qualities [46]. High peak viscosity indicates the high swelling capacity of the starch granules. High peak viscosity of the raw barnyard millet flour $(854 \mathrm{cP})$ and roasted foxtail millet flour $(1143 \mathrm{cP})$ indicates its high water binding capacity resulting in more swelling of the starch granules. The ranges observed in trough viscosity of the raw and processed barnyard millet flour and foxtail millet flour were 21 to $741 \mathrm{cP}$ and 29 to $420 \mathrm{cP}$ respectively.

The breakdown is caused by the disintegration of gelatinized starch granules structure during continued stirring and heating, thus, indicating the shear thinning property of starch [47]. The low breakdown viscosity of both boiled and pressure cooked barnyard millet flour and foxtail millet flour $(2 \mathrm{cP})$ indicates its stability of the starches under hot conditions. Final viscosity indicates the ability of the starch to form a viscous paste. The high final viscosity of the raw barnyard millet flour $(1235 \mathrm{cP})$ and foxtail millet flour $(1398 \mathrm{cP})$ indicates its high resistance to shear.

The setback viscosity is an index of retrogradation. The setback viscosity is the increased in viscosity resulting from the rearrangement of amylose molecules that have leached out from the swollen starch granules during cooling and is generally used as a measure of gelling ability or retrogradation tendency of the starch [48]. The lower setback value of boiled barnyard millet flour $(9 \mathrm{cP})$ and roasted foxtail millet flour $(-107 \mathrm{cP})$ indicated its lowest rate of retrogradation and hence the product made of low set back viscosity flour will have prolonged shelf life period.

\begin{tabular}{|c|c|c|c|c|c|c|}
\hline S.no & Minerals & Boiling & Germination & $\begin{array}{c}\text { Pressure } \\
\text { cooking }\end{array}$ & Roasting & Raw \\
\hline 1. & Sodium (mg) & 22 & 25 & 19 & 16 & 8 \\
\hline 2. & Potassium (mg) & 294 & 320 & 275 & 356 & 252 \\
\hline 3. & Iron (mg) & 2.59 & 5.8 & 3.8 & 2.4 & 3.7 \\
\hline 4. & Calcium (mg) & 40 & 50 & 60 & 31 & 40 \\
\hline 5. & Phosphorus (mg) & 221 & 265 & 247 & 280 & 238 \\
\hline
\end{tabular}

Table 11: Mineral composition of the raw and processed foxtail millet flour (per 100 gms).

\section{Conclusion}

There was a significant variation with respect to functional, nutritional, anti-nutritional and pasting properties of selected two millets in response to different processing methods. Among them, germination reduces the anti-nutritional factors while roasting significantly increases the nutritional compounds. The improved functional and pasting properties were observed in the germinated and roasted millet flours that make them good base ingredients in infant food formulation. Considering the above mentioned benefits, it is recommended that the germinated and roasted millet flours would be of use in food systems where these properties are required.

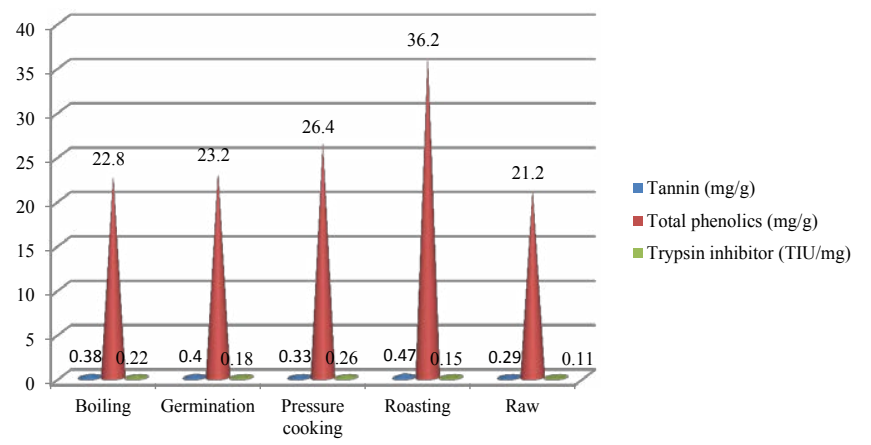

Figure 1: Anti-nutritional parameters of raw and processed Barnyard millet flour.

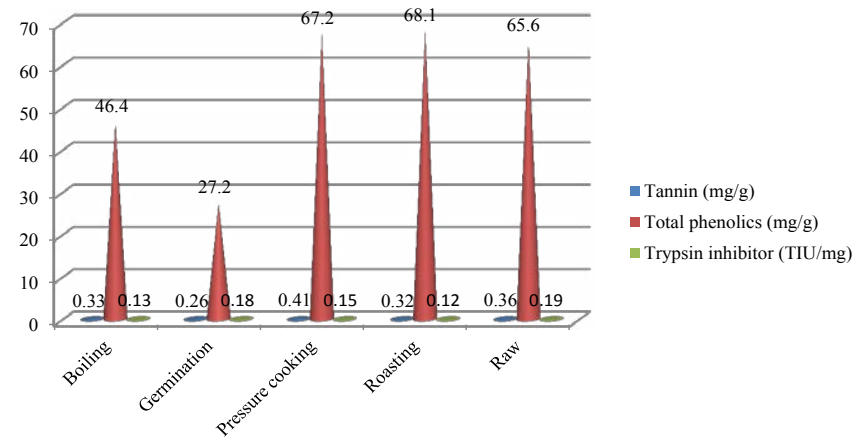

Figure 2: Anti-nutritional parameters of raw and processed Foxtail millet flour.

\begin{tabular}{|c|c|c|c|c|c|c|c|}
\hline S.no & Parameters & Pasting temperature $\left({ }^{\circ} \mathrm{C}\right)$ & Peak viscosity (cP) & Trough viscosity (cP) & Breakdown viscosity (cP) & $\begin{array}{l}\text { Final viscosity } \\
\text { (cP) }\end{array}$ & $\begin{array}{c}\text { Setback } \\
\text { viscosity (cP) }\end{array}$ \\
\hline 1. & Boiling & 48.25 & 23 & 21 & 2 & 30 & 9 \\
\hline 2. & Germination & 49.55 & 70 & 21 & 49 & 32 & 11 \\
\hline 3. & Pressure cooking & 48.35 & 31 & 29 & 2 & 44 & 15 \\
\hline 4. & Roasting & 94.45 & 101 & 93 & 8 & 196 & 103 \\
\hline 5. & Raw & 90.4 & 854 & 741 & 113 & 1235 & 494 \\
\hline
\end{tabular}

Table 12: Pasting properties of the raw and processed barnyard millet flour.

\begin{tabular}{|c|c|c|c|c|c|c|c|}
\hline S:No: & Parameters & $\begin{array}{l}\text { Pasting temperature } \\
\qquad\left({ }^{\circ} \mathrm{C}\right)\end{array}$ & $\begin{array}{l}\text { Peak viscosity } \\
\text { (cP) }\end{array}$ & $\begin{array}{c}\text { Trough viscosity } \\
\text { (cP) }\end{array}$ & $\begin{array}{l}\text { Breakdown viscosity } \\
\text { (cP) }\end{array}$ & $\begin{array}{l}\text { Final viscosity } \\
\text { (cP) }\end{array}$ & $\begin{array}{c}\text { Setback viscosity } \\
\text { (cP) }\end{array}$ \\
\hline 1. & Boiling & 48.50 & 41 & 39 & 2 & 59 & 20 \\
\hline 2. & Germination & 48.60 & 116 & 48 & 68 & 90 & 42 \\
\hline 3. & Pressure cooking & 48.50 & 31 & 29 & 2 & 37 & 8 \\
\hline 4. & Roasting & 50.2 & 1143 & 361 & 782 & 254 & -107 \\
\hline 5. & Raw & 89.6 & 521 & 420 & 101 & 1398 & 978 \\
\hline
\end{tabular}

Table 13: Pasting properties of the raw and processed foxtail millet flour. 
Citation: Nazni P, Devi SR (2016) Effect of Processing on the Characteristics Changes in Barnyard and Foxtail Millet. J Food Process Technol 7: 566. doi:10.4172/2157-7110.1000566

Page 7 of 8

\section{Acknowledgement}

The first author is grateful to DST-SERB for providing financial assistance to carry out the work.

\section{References}

1. Bavec F, Bavec M (2006) Millets in organic production and use of alternative crops. CRC Press, London.

2. Mal B, Padulosi S, Ravi SB (2010) Minor millets in South Asia: Learnings from IFAD-NUS project in India and Nepal. MS Swaminathan Research Foundation $1-185$.

3. Devi PB, Vijayabharathi R, Sathyabama S, Malleshi NG, Priyadarisini VB, et al. (2014) Health benefits of finger millet (Eleusine coracana L.) polyphenols and dietary fiber: a review. J Food Sci Technol 51: 1021-1040.

4. Pradeep SR, Guha M (2011) Effect of processing methods on the nutraceutical and antioxidant properties of little millet (Panicum sumatrense) extracts. Food Chem 126: 1643-1647.

5. Li J, Chen Z, Guan X, Liu J, Zhang M, et al. (2008) Optimization of germination conditions to enhance hydroxyl radical inhibition by water soluble protein from stress millet. J Cereal Sci 48: 619-624.

6. Ahmed SM, Zhang Q, Chen J, Shen Q (2013) Millet Grains: Nutritional quality, processing and potential health benefits. Comprehensive Reviews in Food Science and Food Safety 12: 281-295.

7. Hotz C, Gibson RS (2007) Traditional food-processing and preparation practices to enhance the bioavailability of micronutrients in plant-based diets. J Nutr 137: 1097-1100.

8. Ige MM, Ogunsua AO, Oke OL (1984) Functional properties of the protein of some Nigerian oilseed, conophor seed and 3 varieties of melon seed. J Agri Food Chem 32: 822-825.

9. Shin M, Gang DO, Song JY (2010) Effects of protein and transglutaminase on the preparation of gluten-free rice bread. Food Sci Biotechnol 19: 951-956.

10. Lin MJY, Humbert ES, Sosulski FW (1974) Certain functional properties of sunflower meal products. J Food Sci 39: 368-370.

11. Sadasivam S, Manickam A (2005) Biochemical Methods. New Age International Publishers.

12. Tester RF, Morrison WR (1990) Swelling and gelatinization of cereal starches II. Waxy rice starches Cereal Chemistry 67: 551-557.

13. Phattanakulkaewmorie N, Paseephol T, Moongngarm A (2011) Chemical compositions and physico-chemical properties of malted sorghum flour and characteristics of gluten free bread. World Academy of Science, Engineering and Technology 57: 454-459.

14. Urbano G, Lopez-Jurado M, Frejnagel S, Gomez-Villalva E, Porres JM, et al. (2005) Nutritional assessment of raw and germinated pea (Pisum Sativum L.) protein and carbohydrate by in vitro and in vivo techniques. Nutrition 21: 230239.

15. Parde SR, Johal A, Jayas DS, White NDG (2003) Physical properties of buckwheat cultivars. Canadian Bio-systems Engineering, Technical Note.

16. Merill AY, Walt BK (1973) Energy value of food basis and derivation. USA dep of agric $74: 2-4$.

17. Omegie HNA, Ogunsakin R (2013) Assessment of chemical, rheological and sensory properties of fermented maize-cardaba banana complementary food. Food and Nutrition Sciences 4: 844-850.

18. Ugare R (2008) Health benefits, Storage quality and value addition of barnyard millet (Echinochloa frumentacaea Link). College of Rural Home Science. University of Agricultural Sciences, Dharwad.

19. Bhupender SK, Rajneesh B, Baljeet SY (2013) Physico chemical, functional, thermal and pasting properties of starches isolated form pearl millet cultivars. International Food Research Journal 20: 1555-1561.

20. Reungmaneepaitoon S, Sikkhamondhol C, Tiangpook C (2006) Nutritive improvement of instant fried noodles with oat bran. J Sci Technol 28: 89-97.

21. Bello-Pérez LA, Contreras-Ramos SM, Jìmenez-Aparicio A, Paredes-López O (2000) Acetylation and characterization of banana (Musa paradisiaca) starch. Acta Cient Venez 51: 143-149.

22. Housson P, Ayenor GS (2002) Appropriate processing and food functional properties of maize flour. Afr J Sci Technol 3: 121-126.

23. Kinsella JE (1982) Relationship between structural and functional properties of food proteins. Food protein. Applied Science Publishers, London: 51-103.

24. Schoch TJ (1964) Swelling power and solubility of granular starches. Academic Press, New York 106-108.

25. Balogun IO, Olatidoye OP (2010) Functional properties of dehulled and undehulled velvet beans flour (mucuna utilis). Journal of Biological Sciences and Bioconservation.

26. Butt MS, Batool R (2010) Nutritional and functional properties of some promising legumes protein isolates. Pakistan J Nutr 9: 373-379.

27. Ajayi IA, Oderinde RA, Kajogbola DO, Uponi JI (2006) Oil content and fatty acid composition of some underutilized legumes from Nigeria. Food Chem 99 $15-120$

28. Ghadivel RA, Prakash J (2007) The impact of germination and dehulling on nutrients, anti-nutrients, in vitro iron and calcium bioavailability and in vitro starch and protein digestibility of some legume seeds. LWT 40: 1292-1299.

29. Kaushik G, Satya S, Naik SN (2010) Effect of domestic processing techniques on the nutritional quality of the soyabean. Mediterranean Journal of Nutrition and Metabolism 1: 39-46.

30. Khatoon N, Prakash J (2006) Nutrient retention in microwave cooked germinated legumes. Food Chem 97: 115-121.

31. Yadav BS, Yadav RB, Kumar M (2011) Suitability of pigeon pea and rice starches and their blends for noodle making. LWT Food Science and Technology 44: 1415-1421.

32. Champ M, Langkilde AM, Brouns F, Kettlitz B, Collet $Y$ (2003) Advances in dietary fibre characterization. Definition of dietary fibre, physiological relevance, health benefits and analytical aspects. Nutrition Research Reviews 16: 71-82.

33. Mubarak AE (2005) Nutritional composition and anti-nutritional factors of mungbean seeds (Phaseolus aureus) as affected by some home traditional processes. J Food Chem 89: 489-495

34. Akinijayeju O, Francis (2007) Effects of sprouting on the proximate composition of bambara nut flours. Processing of the annual conference/general meeting of NFST 25: 158-159.

35. Aremu MO, Olayioye YE, Ikokoh PP (2009) Effect of processing on nutritiona quality of kersting groundnut (Kerstingiella geocarpa L.) seed flours. J Chem Soc Nig 34: 140-149.

36. Parameswaran K, Sadasivam S (1994) Changes in the carbohydrates and nitrogenous components during germination of proso millet (Panicum miliaceum). Plants Foods Hum Nutr 45: 97-102.

37. Srichuwong S, Suharti C, Mishima T, Isono M, Hisamatsu M (2005) Starches from different botanmical sources: Contribution of starch structure to swelling and pasting properties. Carbohydrate polymers 62: 25-34.

38. Sprouting (2008) Nutritional information. Wikipedia.

39. Deorthale GY, Rao U (2006) Polyphenoloxidase activity in germinated legume seeds. Journal of food science.

40. El-Adawy TA, Taha KM (2001) Characteristics and composition of watermelon, pumpkin, and paprika seed oils and flours. J Agric Food Chem 49: 1253-1259.

41. Platel K, Eipeson SW, Srinivasan R (2010) Bioaccessible mineral content of malted finger millet (Eleusine coracana), wheat (Triticum aestivum), and barley (Hordeum vulgare). J Agric Food Chem 58: 8100-8103.

42. Seifi MR, Alimardani R, Akram A, Asakereh A (2010) Moisture-depend physical properties of safflower (Goldasht). Advance Journal of Food Science and Technology 2: 340-345

43. Sahlin E, Savage GP Lister CE (2004) Investigation of the antioxidant properties of tomatoes after processing. Journal of Food Composition and Analysis 17: 635-647.

44. Sivashanthini K, Vivekshan Reval S, Thavaranjith AC (2012) Comparative study on organoleptic, microbiological and biochemical qualities of commercially and experimentally prepared salted and sun dried talang queen fish, scomberoides commersonianus. Asian Journal of Animal and Veterinary Advances 7: 1279-1289.

45. Kaur M, Singh N (2005) Studies of functional, thermal and pasting properties of flours from different chickpea (Cicer arietinum L.) cultivars. Food Chemistry 91: 403-411. 
Citation: Nazni P, Devi SR (2016) Effect of Processing on the Characteristics Changes in Barnyard and Foxtail Millet. J Food Process Technol 7: 566. doi:10.4172/2157-7110.1000566

Page 8 of 8

46. Taiwo OO, Jimoh D, Osundeyi E (2010) Functional and pasting properties of composite cassava-sorgum flour meals. Agriculture and Biology Journal of North America 1: 715-720.

47. Zhang D, Hamauzu Y (2004) Phenolics, ascorbic acid, carotenoids and antioxidant activity of broccoli and their changes during conventional and microwave cooking. Food Chemistry 88: 503-509.

48. Karim AA, Toon LC, Lee VP, Ong WY, Fazilah A, et al. (2007) Effects of phosphorus contents on the gelatinization and retrogradation of potato starch. J Food Sci 72: 132-138. 